\title{
Grease or Sand the Wheels? A State-Level Approach on Corruption in Brazil
}

\author{
Francisco Germano Carvalho Lucioㅁ, Ricardo A. de Castro Pereira', José Weligton Félix Gomes ${ }^{2}$ \\ ${ }^{1}$ Department of Economics, Federal University of Ceará, Fortaleza, Brazil \\ ${ }^{2}$ Department of Economics and Finances, Federal University of Ceará (UFC/Sobral), Sobral, Brazil \\ Email: germanocarvalho@caen.ufc.br,rpereira@caen.ufc.br, weligtongomes@gmail.com
}

How to cite this paper: Lucio, F. G. C., de Castro Pereira, R. A., \& Gomes, J. W. F. (2020). Grease or Sand the Wheels? A StateLevel Approach on Corruption in Brazil. Theoretical Economics Letters, 10, 620-634. https://doi.org/10.4236/tel.2020.103040

Received: May 10, 2020

Accepted: June 19, 2020

Published: June 22, 2020

Copyright (c) 2020 by author(s) and Scientific Research Publishing Inc. This work is licensed under the Creative Commons Attribution International License (CC BY 4.0).

http://creativecommons.org/licenses/by/4.0/

\begin{abstract}
This paper investigates the effects of corruption on income per capita over Brazilian states. Given the absence of proxies for corruption in this subnational level, it creates objective proxies for that. To achieve more accuracy on analyses, this paper also controls for spatial correlation. Although corruption had presented a negative and significant effect on aspatial models, it is indeed nonsignificant as long as it controls for spatial dependence. Hence, it seems corruption has no impact on GDP per capita at the state-level in Brazil. Therefore, neither the "grease the wheels" nor the "sand the wheels" hypothesis fits the Brazilian states.
\end{abstract}

\section{Keywords}

Brazilian States, Corruption, Spatial Analysis

\section{Introduction}

Corruption is a world phenomenon, a common problem the governments must face. Once corruption takes away part of the public resources available, the magnitude of the effects depends on, among other factors, the level of observed corruption. Additionally, it fosters an inefficient allocation of these resources yielding outputs lower than it could potentially be. Therefore, in small and poor economies in which resources are usually scarcer, each portion of wasted resources tends to be proportionally more costly.

Although the recent scandals of corruption in Brazil have been focused on the central government, they involve the state-level governments as well. As a result, it not only undermines the trust the individuals, voters and investors, lodge in government but also implies different fiscal problems. In order words, corruption may lead to political instability, which is an important channel through 
which corruption affects economic growth (Mo, 2001 and Ghalwash, 2014). According to Solé-Ollé and Sorribas-Navarro (2018), after a scandal capital grants from higher tiers of government tend to fall. Conversely, taxes and deficit tend to increase. Besides, local governments do not adjust their spending as a response to the corruption effects. All these results have a potential negative influence on economic indicators.

A sizeable body of literature of corruption and growth issues uses subjective indexes such as the Corruption Perception Index and the control of corruption indicator, which are available for country-level only. On the other hand, just a smaller share of this literature has applied objective proxies for corruption. Regarding analyses in the Brazilian territory, Ferraz and Finan (2011) created an objective measurement for corruption by using reports from an anti-corruption program in the Brazilian municipalities. Concerning a state-level corruption, in turn, Boll (2010) created the State-level Government Corruption Indicator. The latter, however, only performs analyses by ranking them in terms of their corruption levels.

Taking Brazil as the target region and also considering local governments as mentioned in the previous paragraph, the literature concerning corruption analyses mostly uses municipalities as the geographical divisions and takes into account different topics such as elections (Ferraz and Finan, 2011 and Brollo, 2012), corruption itself (Avis et al., 2018), and economic outcomes (Bologna, 2017). It still lacks a paper to investigate corruption and income outcomes by using an objective measurement of corruption at the state level in Brazil.

Besides, according to LeSage and Fischer (2008), income issues commonly present spatial dependence among the analyzed units. In the context of the Brazilian states, spatial correlation indicates that wealthier states tend to be geographically clustered as well as the poorest ones. There is no work into the literature taking the Brazilian states as a spatial approach and including corruption and income issues.

Therefore, this paper aims to fulfill the gap discussed in the two previous paragraphs. Thus, the main contribution of this paper is to create an objective proxy for corruption and apply it in analyses concerning income issues in state-level Brazil. Furthermore, to achieve more accuracy in the connection among the Brazilian states, this paper also performs a spatial approach of the aforementioned intended analysis.

Beyond this introduction, this paper is organized into four more sections, as follows. The next section presents a literature review. In section three are specified the methodology and data. The fourth section displays the results split into different econometric approaches. Finally, the last one highlights the main conclusions.

\section{Literature Review}

As an essential driver for economic growth, the investment can also be a trans- 
mission channel of the effects of corruption on growth as shown by Pellegrini and Gerlach (2004). As long as corruption yields uncertainty over the economic environment and discourages investment activities, it presents negative effects on economic growth, as shown in Mauro (1995, 1997, 1998), Ahmad et al. (2012), and Cieślik and Goczec (2018), among others. Hence, it has impacts on investments in open economies, which, in turn, can hamper economic growth. Nevertheless, this negative relationship between corruption and economic growth has been increasingly presented in the literature since the work of Myrdal (1989).

As slightly shown in the previous paragraph, corruption might harm economic growth. This standpoint is compatible with the "sand the wheels" hypothesis. Indeed, the literature investigates corruption and poverty levels such as Easterly (2005), Dike (2005), and Alenoghena and Evans (2015). Dike (2005) claims that corruption works as a poverty enlarger and Alenoghena and Evans (2015) classify the effects as perverse and dangerous. Also, Gyimah-Brempong (2002) combined both economic growth and income inequality with corruption.

An alternative proxy to link the relationship between corruption and economic issues has been increasingly applied in the literature, the control of corruption indicator. In this case, the link is supposed to be positive assuming corruption is mostly considered as a negative factor. Indeed, works such as Hall and Levendis (2017), Cieślik and Goczek (2018), Sharma and Mitra (2019), and Leite et al. (2019) found a positive relationship between control of corruption and economic growth, among other results specific from each work and considering different variables. It is noteworthy that Leite et al. (2019) focused on the long-term effects of that relationship.

Despite the abovementioned negative relationship between corruption and economic growth, works such as Bardhan (1997), Huntington and Fukuyama (2006), and Thach et al. (2017), among others, conversely present a positive relationship for that. Similar results are found by Wang (2016) by using the Chinese Anti-corruption campaign as an alternative measurement. In this context, the "grease the wheels" hypothesis is an alternative to explain that corruption might reduce bureaucracy, hence it might positively affect economic activities in specific cases such as countries with higher regulation. Corruption activities may reduce barriers to investment yielding positive economic stimulus (Méon and Weil, 2010) as well as works specifically concerning foreign direct investment (Egger and Winner, 2005).

The literature concerning corruption in the Brazilian subnational units presents reasons such as elections and also corruption itself (Ferraz and Finan, 2011, Brollo, 2012 and Avis et al., 2018). However, in terms of economic issues, Bologna $(2016,2017)$, using data from different samples of Brazilian municipalities, found that both higher levels of corruption and a huge informal sector are associated with lower economic outcomes. Nevertheless, only the informal sector presented a significant effect on it. 
Studies applying spatial approaches to economic growth and income issues are relatively new. Rey and Montouri (1999) had first explored the regional income convergence process in the US by applying a spatial approach to it. Then, this approach has been spread around the world becoming popular throughout the years. As some examples, there are Magalhães et al. (2005) in Brazil; Dall'erba and Le Gallo (2008) and Dall'erba et al. (2008) in Europe; and Hou and Long (2019) in China. However, there is no previous work including corruption and economic issue allowing for spatial dependence taking the Brazilian states as the target units.

\section{Estimation Methods and Data}

\subsection{Aspatial Econometric Model}

Since Brazil has only 27 states, therefore insufficient to yield reliable results by using a cross-section approach, a panel data approach is instead applied considering a time range from 2005 to 2013. The standard static panel data model, from Greene (2002), for units $i=1, \cdots, 27$ and time $t=1, \cdots, 9$ is shown as follows.

$$
y_{i, t}=\boldsymbol{x}_{i, t}^{\prime} \boldsymbol{\beta}+\boldsymbol{z}_{i}^{\prime} \boldsymbol{\alpha}+\varepsilon_{i, t}
$$

where $\boldsymbol{x}_{i, t}$ is a vector of explanatory variables, $\boldsymbol{z}_{i}^{\prime}$ represents the heterogeneity, in which $z_{i}$ accommodate a constant term and a set of either observed or unobserved specific variables, and $\boldsymbol{\beta}$ the vector of the slopes, independent of $i$ and $t$. Finally, the error term, $\varepsilon_{i, t}$, varies over units and time.

Once investigate the effects of corruption on income is the main goal in this study, proxies for corruption objectively measured are added. Besides, variables others than those presented in traditional models such as Mankiw et al. (1992) are included to avoid the problem of omitted variable bias. The variables used are the stock of physical capital, human capital, public investment, unemployment, and corruption. All of these variables and proxies are detailed in subsection 3.3.

\subsection{Spatial Econometric Model}

Spatial autocorrelation refers to the coincidence of attribute similarity and locational similarity (Anselin, 1988). In econometric modeling, spatial methods are required as long as data are correlated over space. It might either solve the problem or mitigate it. Although the literature in this field has been applied mostly in cross-sectional spatial dependence models, there is a relatively recent development in the class of spatial panel models. The estimations outperform those obtained from both the aspatial and non-panel modeling as they are not biased and efficient (Elhorst, 2010).

Le Gallo et al. (2003) applied the spatial lag model (SAR) and the spatial error model (SEM) on cross-sectional regional convergence. Conversely, Arbia et al. (2005) are considered the pioneers to include this type of spatial autocorrelation effects in a panel data framework. Following Elhorst (2003), they expanded the above-mentioned analysis from Le Gallo et al. (2003) to a panel data approach. 
Since there are only 27 states in Brazil, not enough to achieve reliable results in a cross-section approach, panel data is the best approach to this case. The time range used is from 2005 to 2013. Based on Millo and Piras (2012), the static SARAR panel data model is applied in this paper. This specification also allows for interaction effects involving the disturbances (LeSage, 2014), as following specified.

$$
y=\lambda\left(I_{T} \otimes W_{N}\right) y+X \beta+u
$$

with $u=\left(l_{T} \otimes I_{N}\right) \mu+\varepsilon$ and $\varepsilon=\rho\left(I_{T} \otimes W_{N}\right) \varepsilon+v$

$$
v_{i t} \sim N\left(0, \sigma_{v}^{2}\right)
$$

where $y$ is the vector of the dependent variable, $X$ is the matrix of non-stochastic exogenous regressors, already mentioned in the previous section, $I_{T}$ is an identity matrix of dimension $T, l_{T}$ is a vector of ones, and $W_{N}$ is the spatial weight matrix and $\lambda$ the spatial autoregressive coefficient. The idiosyncratic errors $(\varepsilon)$ are spatially autocorrelated, in which $\rho$ represents the spatial autoregressive parameter, $\mu$ is a not-spatially-autocorrelated individual effect. This structure comes from Baltagi et al. (2003). Given there is no consensus in the literature for the notation of these parameters, this paper applies the same as Millo and Piras (2012). Although, they appear differently on other papers as briefly shown in Bivand and Piras (2015).

\subsection{Data and Spatial Weight Matrix}

The data used in this paper were collected in different official sources from the government. Each component of the data is in a different time series length, hence the intersection of them was considered as a way to amplify the time component. Thus, a nine-year range was selected, from 2005 to 2013. The GDP per capita is used as the dependent variable to represent the income. This data was collected from the Applied Economics Research Institute-IPEA ${ }^{1}$. The values were deflated by the GDP implicit deflator, which is the most appropriate for this variable.

The proxy used for physical capital is the consumption of non-residential electric power. This is the best option available due to the fact it takes into account all of the economic sectors as opposed to another widely used proxy, electric power spent in the industry sector.

This paper follows Mankiw et al. (1992) and it includes a human capital proxy. The literature concerning human capital has focused on considering the quality of education instead of only some type of quantity of it. In this regard, a proxy combining both quantity and quality of education was created by using Years of Schooling ${ }^{2}$ as the quantity part and the High School level of the Basic Education Development Index-IDEB ${ }^{3}$ as the quality part. Taking only the high school lev${ }^{1}$ Available at http://www.ipeadata.gov.br/.

${ }^{2}$ Years of schooling from the population legally able to work. Available in IBGE website https://www.ibge.gov.br/.

${ }^{3}$ Available at: http://ideb.inep.gov.br/resultado/resultado/resultado.seam?cid=1211699. 
el for IDEB increases the accuracy since students finish high school with age legally able to work.

Additionally, to strengthen the model specification, extra variables others than corruption are added, namely that, public investment and the unemployment rate. Public investments are deflated by a proper index and represent the acquisition of facilities, equipment, and creation or increase in the stock of capital. The decision for unemployment specifically lies in a theoretical motivation provided by Bräuninger and Pannenberg (2002).

Using data from the Irregular Accounts Register of the Federal Court of Accounts as the main source Boll (2010) created a corruption index based on data from irregular reports concerning the state-level governments' spends. A governmental agency, the Federal Government Accounts Court, is responsible for either accepting or overruling the reports. The assumption behind this measurement is to consider the overruled reports as a source of corruption. The composition of this index also includes GDP and Population as weights for the values from the above-mentioned irregular reports.

This paper applies two proxies for corruption. The first one uses the same components present in the index created by Boll (2010). It is called the corruption index of Brazilian states 1, in short Corruption 1, and it is described in equation 3. The second one excludes the components weighted by population and GDP as an attempt to expurgate possible endogeneity problems. Therefore, it takes into account only two components, namely that, the value of the Irregular Accounts-VIA from the Federal Court of Accounts as a share of the Annual Budget Law-ABL and the annual number of irregular cases as a share of the total cases. It is, in turn, called the corruption index of Brazilian states 2, briefly Corruption 2, as described in Equation (4).

$$
\begin{gathered}
\text { Corruption }_{i, t}=0.25\left(\frac{V I A_{i, t}}{\text { Pop }_{i, t}}+\frac{\text { VIA }_{i, t}}{G D P_{i, t}}+\frac{\text { VIA }_{i, t}}{A B L_{i, t}}+\frac{\text { Cases }_{i, t}}{\text { Total }_{t}}\right) \\
\text { Corruption }_{i, t}=0.5\left(\frac{V I A_{i, t}}{\text { ABL }_{i, t}}+\frac{\text { Cases }_{i, t}}{\text { Total }_{t}}\right)
\end{gathered}
$$

where $i$ and $t$ represent the states and the time respectively.

Finally, this paper uses a Queen type weight matrix, which classifies the neighbors in contiguity. Anselin (2018) claims that using the queen criterion is recommended in practice to deal with potential inaccuracies in the polygon file such as rounding errors. It makes this type to be considered as the default for contiguity weights.

\section{Results and Discussion}

The results are divided into two parts based on the absence and presence of spatial dependence. Model specifications 1 and 2 are used to refer to the regressions using respectively the proxies for corruption 1 and 2 . Henceforth, only the model designations are applied. 


\subsection{Results from the Aspatial Regressions}

The tests required to guarantee reliable estimations are performed. Firstly, to verify individual effects, the $\mathrm{F}$ test detected significant interstate variation. It suggests that the fixed effect specification is more relevant than the pooled one for both models 1 and 2. Additionally, the Lagrange Multiplier Test for panel models, which tests of individual and/or time effects for panel models, are performed for both fixed and random effects. Using the Breusch-Pagan type, from Breusch and Pagan (1980), they confirm that both fixed and random models outperform the pooled model for both models 1 and 2. Then, the well-known Hausman specification test, from Hausman (1978), assessed that the fixed effect model fits better than the random effect.

Studies such as Gupta et al. (2000) and Reinikka and Svensson (2005) have shown that corruption may reduce human capital levels. Based on that, the Variance Inflation Factors (VIF) test was performed, from Fox and Monette (1992), and no multicollinearity was detected. Another test related to these issues, the Breusch-Pagan test, from Breusch and Pagan (1979), for heteroscedasticity is also required in panel data approaches. It reports the expected presence of that.

Additionally, two tests were performed to check for serial correlation, the Breusch-Godfrey test, from Breusch (1979) and Godfrey (1978), and The Wooldridge, from Wooldridge (2010). The first test for serial correlation in the idiosyncratic component of the error terms and the second performs that specifically in fixed-effects panel models. The results of both tests confirm the presence of serial correlation.

Given the presence of heteroscedasticity as well as of serial correlation, the estimation must apply the widely recommended method of Arellano, from Arellano (1987), for fixed effects panel data models, which treats simultaneously for both heteroscedasticity and serial correlation yielding, as a result, heteroscedasticity consistent standard errors. The results are shown in Table 1 .

First of all, assuming that negative effects from corruption on economic activity are possible, all of the coefficients presented the expected signal for both models proposed. Specifically, physical capital, human capital, and public investments affect positively the level of income per capita in Brazilian states. Conversely, unemployment and corruption yield negative effects on that. Considering all of the performed tests and the treatment for the specific problems detected, roughly speaking, it seems that both models are well specified. In terms of significance, in turn, correcting by the Arellano consistent standard errors, only corruption is nonsignificant in Model 1. It marginally crosses the borderline of significance becoming nonsignificant. Nevertheless, all of the coefficients are significant in model 2 .

Notwithstanding the above results and as previously mentioned in the introduction section, income issues commonly present spatial dependence among the analyzed units (LeSage and Fischer, 2008). Therefore, there exists a strong possibility that income per capita among the Brazilian states presents some sort of 
Table 1. Estimation of fixed effect (FE) panel data, 2005-2013.

\begin{tabular}{ccccc}
\hline & \multicolumn{4}{c}{ Panel Data (FE) } \\
\cline { 2 - 5 } & \multicolumn{3}{c}{ Model 1 } & Nodel 2 \\
\cline { 2 - 5 } & Normal & Arellano & $0.4735^{* * *}$ & $0.4735^{* * *}$ \\
\hline \multirow{2}{*}{ Physical Capital } & $0.4583^{* * *}$ & $0.4583^{* * *}$ & $(0.000)$ & $(0.000)$ \\
& $(0.000)$ & $(0.000)$ & $0.3744^{* * *}$ & $0.3744^{* * *}$ \\
Human Capital & $0.4045^{* * *}$ & $0.4045^{* * *}$ & $(0.000)$ & $(0.000)$ \\
& $(0.000)$ & $(0.000)$ & $-0.0790^{* * *}$ & $-0.0790^{* *}$ \\
Unemployment & $-0.0766^{* * *}$ & $-0.0766^{* *}$ & $(0.003)$ & $(0.028)$ \\
& $(0.004)$ & $(0.037)$ & $0.0476^{* * *}$ & $0.0476^{* * *}$ \\
Investment & $0.0464^{* * *}$ & $0.0464^{* * *}$ & $(0.000)$ & $(0.000)$ \\
Corruption 1 & $(0.000)$ & $(0.002)$ & & \\
Corruption 2 & $-0.0510^{*}$ & -0.0510 & & $-0.0274^{*}$ \\
R-Squared & $(0.093)$ & $(0.109)$ & $0.066)$ \\
Adj. R-Squared & & & $(0.014)$ & 0.7927 \\
\hline
\end{tabular}

1) All variables are log transformed. 2) The symbols ${ }^{* * *}$, **, and ${ }^{*}$ denote the significances respectively at $1 \%, 5 \%$, and $10 \%$. 3) The values in parentheses represent the $p$-values.

spatial dependence. If so, the results presented so far might change, mostly in terms of significance. To achieve more accuracy on this approach, this paper also tests for spatial dependence. Once detected, these new estimators must outperform those estimated by the classical aspatial model as long as they are unbiased and efficient (LeSage and Pace, 2009). The tests and regressions are exposed in the following subsection.

\subsection{Results from the Spatial Regressions}

Following the structure of the previous subsection, before the results are shown, tests are performed. Given the fact the aspatial analysis have already detected the presence of heterogeneity in the units, pointing to the usage of fixed effects, there is no reason to perform the panel version of the locally robust Lagrange multiplier tests of Anselin et al. (1996), which is suitable for spatial error dependence based on a pooling assumption only. Instead, the Baltagi, Song, and Koh LM test, from Baltagi et al. (2003) was performed, detecting spatial error correlation.

The tests of Breusch-Pagan (Breusch and Pagan, 1980) and Pesaran (Pesaran, 2004) were performed to check the correlation of the residuals across the states. Both tests indicate significant cross-sectional dependence. This dependence regards an unknown form, not necessarily related to geographically neighbors. Using a Queen-type weight matrix, however, a significant presence of this specific type of spatial dependence was found by performing the well-known Moran's I. This test uses a method presented by Gittleman and Kot (1990). As a ro- 
bustness check, a Monte-Carlo simulation of Moran's I was performed as well.

Many determinant factors might induce spatial dependence in regions. Some examples one may easily find in the literature are trade, mobility of the productive factors, and technology diffusion. A caution worth mentioning, however, is that spatial dependence might be related to omitted variables or other types of model misspecifications. Nevertheless, it must be discarded by the inclusion of extra variables others than those considered in the original model of Mankiw et al. (1992), combined to LeSage and Fischer (2008), who claim that income issues commonly present spatial dependence over the units.

To reinforce the use of fixed effects previously pointed out by the Hausman test, the Hausman specification test for the spatial approach of panel data models was performed, from Mutl and Pfaffermayr (2011). Therefore, combining the results of these tests to the fact that it is highly likely there exists spatial dependence for income issues, in this case in terms of the GDP per capita, this paper applies the SARAR panel data model with fixed effects. These results are displayed in Table 2.

Firstly, measuring the strength of the spatial correlation, the spatial parameters are both significant in both models. In terms of the directions of the effects, again both models present the expected signals. Controlling for spatial dependence, however, only the traditional factors of this production function (physical capital and human capital) as well as unemployment are statistically significant.

In contrast to the aspatial estimations, the magnitudes of the estimated coefficients changed as well. The human capital factor figures as the most important in this spatial approach, given that it represents the largest impact. Conversely, physical capital, which had presented the biggest effect before, now represents the smallest one. Besides, unemployment presents an impact even bigger than physical capital. One likely reason, which also would explain the size of the coefficient of human capital, is the mobility of labor as a productive factor.

On the other hand, in terms of the no significance for corruption, one would claim this is also a possible result as long as Bologna (2017) also found a nonsignificant effect regarding corruption and economic outcomes using, however, data of Brazilian municipalities.

There are two eligible reasons for the absence of significance on corruption related to the theoretically possible negative and positive results, which are linked to the "Sand the wheels" and "Grease the wheels" hypotheses, respectively. Firstly, once corruption on this approach level has been less noticed on the media, it might represent a small and insignificant interference on income drivers such as private investments, in contrast to when it regards the federal government actions. Secondly, since the corruption measurement applied only considers the misuse of public resources excluding, therefore, the treatment of the relationship between public and private sectors as a venue for corruption, there is no way to capture any possible positive effect. Both the no significance and the negative coefficient reassert that. 
Finally, as extra information, Table 3 presents the spatial impacts split as direct and indirect effects as well as the total effects. The spatial impact of a variable is approximated by the indirect effect as a share of the total one. Golgher and Voss (2016) provide a detailed explanation of how to derive and interpret these spatial direct and indirect effects.

Table 2. Spatial regressions of fixed effect SARAR model, 2005-2013.

\begin{tabular}{ccc}
\hline \multirow{2}{*}{ Variables } & \multicolumn{2}{c}{ SARAR Panel Data (FE) } \\
\cline { 2 - 3 } & Model 1 & Model 2 \\
\cline { 2 - 3 } Physical Capital & $0.0433^{* *}$ & $0.0468^{* * *}$ \\
& $(0.011)$ & $(0.009)$ \\
Human Capital & $1.6036^{* * *}$ & $1.5917^{* * *}$ \\
& $(0.000)$ & $(0.000)$ \\
Unemployment & $-0.1203^{* *}$ & $-0.1153^{* *}$ \\
& $(0.027)$ & $(0.036)$ \\
Public Investment & 0.0265 & 0.0280 \\
& $(0.336)$ & $(0.313)$ \\
Corruption 1 & -0.0381 & \\
Corruption 2 & $(0.531)$ & -0.0154 \\
& & $(0.4997)$ \\
Spatial Lag of the Idiosyncratic errors & $0.6371^{* * *}$ & $0.1680^{* * *}$ \\
& $(0.000)$ & $(0.000)$ \\
Spatial Lag of Income per capita & $0.1697^{* *}$ & $0.1680^{* *}$ \\
& $(0.012)$ & $(0.013)$ \\
\hline
\end{tabular}

1) All variables are $\log$ transformed. 2) The symbols ${ }^{* * *}$, ${ }^{* *}$, and ${ }^{*}$ denote the significances respectively at $1 \%, 5 \%$, and $10 \%$. 3) The values in parentheses represent the $p$-values.

Table 3. Estimated direct, indirect, and total effects from spatial regressions.

\begin{tabular}{ccccccc}
\hline & \multicolumn{7}{c}{ SARAR Panel Data (FE) } \\
\cline { 2 - 7 } & \multicolumn{7}{c}{ Model 1 } & & Model 2 & \\
\cline { 2 - 7 } & Direct & Indirect & Total & Direct & Indirect & Total \\
\hline \multirow{2}{*}{ Physical Capital } & $0.04664^{* * *}$ & $0.0056^{* *}$ & $0.0522^{* * *}$ & $0.0503^{* * *}$ & $0.0060^{* *}$ & $0.0563^{* * *}$ \\
& $(0.008)$ & $(0.030)$ & $(0.009)$ & $(0.006)$ & $(0.043)$ & $(0.007)$ \\
Human Capital & $1.7239^{* * *}$ & $0.2076^{* * *}$ & $1.9316^{* * *}$ & $1.7087^{* * *}$ & $0.2046^{* * *}$ & $1.9133^{* * *}$ \\
& $(0.000)$ & $(0.000)$ & $(0.000)$ & $(0.000)$ & $(0.002)$ & $(0.000)$ \\
Unemployment & $-0.1293^{* *}$ & $-0.0155^{*}$ & $-0.1449^{* *}$ & $-0.1238^{* *}$ & $-0.0148^{*}$ & $-0.1386^{* *}$ \\
& $(0.026)$ & $(0.061)$ & $(0.027)$ & $(0.039)$ & $(0.085)$ & $(0.040)$ \\
Public Investment & 0.0285 & 0.0034 & 0.0319 & 0.0300 & 0.0036 & 0.0337 \\
& $(0.411)$ & $(0.431)$ & $(0.411)$ & $(0.291)$ & $(0.349)$ & $(0.295)$ \\
Corruption 1 & -0.0409 & -0.0049 & -0.0459 & & & \\
Corruption 2 & $(0.549)$ & $(0.563)$ & $(0.549)$ & & & \\
& & & & -0.0165 & -0.0019 & -0.0185 \\
& & & & $(0.456)$ & $(0.470)$ & $(0.456)$ \\
\hline
\end{tabular}

1) All variables are log transformed. 2) The symbols ${ }^{* *}$, **, and ${ }^{*}$ denote the significances respectively at $1 \%, 5 \%$, and $10 \% .3$ ) The values in parentheses represent the $p$-values. 


\section{Final Remarks}

This paper investigates the impacts of corruption on income per capita in Brazilian states. Given the absence of proxies in this level of units, this paper created objective proxies to represent corruption. Although corruption had presented a negative and significant effect in the aspatial models, it is indeed nonsignificant when controlling for spatial dependence. Given that the spatial models are theoretically more accurate, it seems there is no impact from corruption on GDP per capita in a state-level approach in Brazil. Hence, neither grease nor sand the wheels' hypothesis drive corruption in Brazilian states.

The nonsignificant results for corruption must not be seen as a green light to stop fighting against it. Even if it does not interfere significantly with the GDP per capita, it still is directly related to the provision of public goods and services, reflecting directly in the well-being of individuals as a whole, which is not the focus of this paper. This sort of result has been shown in the literature mostly by those works applying general equilibrium, such as Zaki (2013).

Finally, since corruption encourages an inefficient allocation of government resources diverting them, it might present distortive effects on economic drivers such as education (Reinikka and Svensson, 2005) and health (Gupta et al., 2000). Therefore, given the possibility of negative indirect effects on income as well as direct effects on its drivers, governments must keep fighting against corruption.

\section{Acknowledgements}

We thank the Brazilian Federal Agency for Support and Evaluation of Graduate Education-CAPES and the Regional Economics Applications LaboratoryREAL-under the ACE Department-the University of Illinois at UrbanaChampaign.

\section{Conflicts of Interest}

The authors declare no conflicts of interest regarding the publication of this paper.

\section{References}

Ahmad, E., Ullah, M. A., \& Arfeen, M. I. (2012). Does Corruption Affect Economic Growth? Latin American Journal of Economics, 49, 277-305. https://doi.org/10.7764/LAJE.49.2.277

Alenoghena, R. O., \& Evans, O. (2015). Corruption Effects on Nigeria: Aggregate and Sectoral Estimates Using VAR. Journal of Economic \& Financial Studies, 3, 41. https://doi.org/10.18533/jefs.v3i02.94

Anselin, L. (1988). Spatial Econometrics: Methods and Models. Berlin: Springer. https://doi.org/10.1007/978-94-015-7799-1

Anselin, L. (2018). Contiguity-Based Spatial Weights. GeoDa Workbook. 03/16/2018. https://geodacenter.github.io/workbook/4a_contig_weights/lab4a.html

Anselin, L., Bera, A. K., Florax, R., \& Yoon, M. J. (1996). Simple Diagnostic Tests for Spa- 
tial Dependence. Regional Science and Urban Economics, 26, 77-104.

https://doi.org/10.1016/0166-0462(95)02111-6

Arbia, G., Basile, R., \& Piras, G. (2005). Using Spatial Panel Data in Modelling Regional Growth and Convergence. ISAE Working Paper No. 55. https://doi.org/10.2139/ssrn.936321

Arellano, M. (1987). Computing Robust Standard Errors for Within-Group Estimators. Oxford Bulletin of Economics and Statistics, 49, 431-434. https://doi.org/10.1111/j.1468-0084.1987.mp49004006.x

Avis, E., Ferraz, C., \& Finan, F. (2018). Do Government Audits Reduce Corruption? Estimating the Impacts of Exposing Corrupt Politicians. Journal of Political Economy, 126, 1912-1964. https://doi.org/10.1086/699209

Baltagi, B. H., Song, S. H., \& Koh, W. (2003). Testing Panel Data Regression Models with Spatial Error Correlation. Journal of Econometrics, 117, 123-150. https://doi.org/10.1016/S0304-4076(03)00120-9

Bardhan, P. (1997). Corruption and Development: A Review of Issues. Journal of Economic Literature, 35, 1320-1346. https://www.jstor.org/stable/2729979

Bivand, R., \& Piras, G. (2015). Comparing Implementations of Estimation Methods for Spatial Econometrics. Journal of Statistical Software, 63, 1-36. https://doi.org/10.18637/jss.v063.i18

Boll, J. L. S. (2010). A corrupção governamental no Brasil. Construção de indicadores e análise da sua incidência relativa nos estados brasileiros. Unpublished Masters Dissertation, Rio Grande do Sul: PUCRS, Porto Alegre.

Bologna, J. (2016). The Effect of Informal Employment and Corruption on Income Levels in Brazil. Journal of Comparative Economics, 44, 657-695. https://doi.org/10.1016/j.jce.2015.12.001

Bologna, J. (2017). Contagious Corruption, Informal Employment, and Income: Evidence from Brazilian Municipalities. The Annals of Regional Science, 58, 67-118. https://doi.org/10.1007/s00168-016-0786-1

Bräuninger, M., \& Pannenberg, M. (2002). Unemployment and Productivity Growth: An Empirical Analysis within an Augmented Solow Model. Economic Modelling, 19, 105-120. https://doi.org/10.1016/S0264-9993(00)00065-1

Breusch, T. S. (1979). Testing for Autocorrelation in Dynamic Linear Models. Australian Economic Papers, 17, 334-355. https://doi.org/10.1111/j.1467-8454.1978.tb00635.x

Breusch, T. S., \& Pagan, A. R. (1979). A Simple Test for Heteroscedasticity and Random Coefficient Variation. Econometrica, 47, 1287-1294. https://doi.org/10.2307/1911963

Breusch, T. S., \& Pagan, A. R. (1980). The Lagrange Multiplier Test and Its Applications to Model Specification in Econometrics. Review of Economic Studies, 47, 239-253. https://doi.org/10.2307/2297111

Brollo, F. (2012). Why Do Voters Punish Corrupt Politicians? Evidence from the Brazilian Anti-Corruption Program. http://dx.doi.org/10.2139/ssrn.2141581

Cieślik, A., \& Goczek, Ł. (2018) Control of Corruption, International Investment, and Economic Growth-Evidence from Panel Data. World Development, 103, 323-335. https://doi.org/10.1016/j.worlddev.2017.10.028

Dall'Erba, S., \& Le Gallo, J. (2008). Regional Convergence and the Impact of European Structural Funds over 1989-1999: A Spatial Econometric Analysis. Papers in Regional Science, 87, 219-245. https://doi.org/10.1111/j.1435-5957.2008.00184.x

Dall'Erba, S., Percoco, M., \& Piras, G. (2008). The European Regional Growth Process 
Revisited. Spatial Economic Analysis, 3, 7-25. https://doi.org/10.1080/17421770701733399

Dike, V. E. (2005). Corruption in Nigeria: A New Paradigm for Effective Control. Africa Economic Analysis, 24, 1-22.

Easterly, W. (2005). Can Foreign Aid Save Africa. In Clemens Lectures, Series 17. Jamaica: Saint John's University.

Egger, P., \& Winner, H. (2005). Evidence on Corruption as an Incentive for Foreign Direct Investment. European Journal of Political Economy, 21, 932-952.

https://doi.org/10.1016/j.ejpoleco.2005.01.002

Elhorst, J. P. (2003). Specification and Estimation of Spatial Panel Data Models. International Regional Science Review, 26, 244-268. https://doi.org/10.1177/0160017603253791

Elhorst, J. P. (2010). Dynamic Panels with Endogenous Interaction Effects When T Is Small. Regional Science and Urban Economics, 40, 272-282. https://doi.org/10.1016/j.regsciurbeco.2010.03.003

Ferraz, C., \& Finan, F. (2011). Electoral Accountability and Corruption: Evidence from the Audits of Local Governments. American Economic Review, 101, 1274-1311. https://doi.org/10.1257/aer.101.4.1274

Fox, J., \& Monette, G. (1992). Generalized Collinearity Diagnostics. JASA, 87, 178-183. https://doi.org/10.1080/01621459.1992.10475190

Ghalwash, T. (2014). Corruption and Economic Growth: Evidence from Egypt. Modern Economy, 5, 1001-1009. https://doi.org/10.4236/me.2014.510092

Gittleman, J. L., \& Kot, M. (1990). Adaptation: Statistics and a Null Model for Estimating Phylogenetic Effects. Systematic Zoology, 39, 227-241. https://doi.org/10.2307/2992183

Godfrey, L. G. (1978). Testing Against General Autoregressive and Moving Average Error Models When the Regressors Include Lagged Dependent Variables. Econometrica, 46, 1293-1302. https://doi.org/10.2307/1913829

Golgher, A. B., \& Voss, P. R. (2016). How to Interpret the Coefficients of Spatial Models: Spillovers, Direct and Indirect Effects. Spatial Demography, 4, 175-205. https://doi.org/10.1007/s40980-015-0016-y

Greene, W. H. (2002). Econometric Analysis (5th ed., p. 802). Upper Saddle River, NJ: Prentice Hall.

Gupta, S., Davoodi, H. R., \& Tiongson, E. (2000). Corruption and the Provision of Health Care and Education Services. IMF Working Papers WP 00/116. https://doi.org/10.1596/1813-9450-2439

Gyimah-Brempong, K. (2002). Corruption, Economic Growth, and Income Inequality in Africa. Economics of Governance, 3, 183-209. https://doi.org/10.1007/s101010200045

Hall, J., \& Levendis, J. (2017). The Efficient Corruption Hypothesis and the Dynamics between Economic Freedom, Corruption, and National Income. Working Paper Series, N. 17-06, Morgantown, WV: Department of Economics, West Virginia University.

Hausman, J. A. (1978). Specification Tests in Econometrics. Econometrica, 46, 1251-1271. https://doi.org/10.2307/1913827

Hou, S. J., \& Long, W. (2019). The Relationship between Transportation Infrastructure Investment and Economic Growth: Based on Provincial Spatial Panel Data Model. In 4th International Conference on Financial Innovation and Economic Development (pp 78-83). Advances in Economics, Business and Management Research Vol. 76, Paris: Atlantis Press. https://doi.org/10.2991/icfied-19.2019.14 
Huntington, S. P., \& Fukuyama, F. (2006). Political Order in Changing Societies. London: Yale University Press.

Le Gallo, J., Ertur, C., \& Baumont, C. (2003). A Spatial Econometric Analysis of Convergence across European Regions, 19801995. In B. Fingleton (Ed.), European Regional Growth (pp. 99-129). Berlin: Springer. https://doi.org/10.1007/978-3-662-07136-6_4

Leite, N., Carvalho Lucio, F., \& Ferreira, R. (2019). Long-Term Effects of Corruption Control and Economic Freedom on Economic Growth. Theoretical Economics Letters, 9, 2965-2974. https://doi.org/10.4236/tel.2019.98183

LeSage, J. P. (2014). What Regional Scientists Need to Know about Spatial Econometrics (January 5, 2014). https://doi.org/10.2139/ssrn.2420725

LeSage, J. P., \& Pace, R. K. (2009). Introduction to Spatial Econometrics. Boca Raton, FL: CRC Press. https://doi.org/10.1201/9781420064254

LeSage, J., \& Fischer, M. (2008). Spatial Growth Regressions: Model Specification, Estimation and Interpretation. Spatial Economic Analysis, 3, 275-304. https://doi.org/10.1080/17421770802353758

Magalhães, A., Hewings, G., \& Azzoni, C. (2005). Spatial Dependence and Regional Convergence in Brazil. Journal of Regional Research, 6, 5-20.

Mankiw, N. G., Romer, D., \& Weil, D. (1992). A Contribution to the Empirics of Economic Growth. The Quarterly Journal of Economics, 107, 407-437.

https://doi.org/10.2307/2118477

Mauro, P. (1995). Corruption and Growth. The Quarterly Journal of Economics, 110, 681-712. https://doi.org/10.2307/2946696

Mauro, P. (1997). The Effects of Corruption on Growth, Investment, and Government Expenditure: A Cross-Country Analysis. In Corruption and the Global Economy (pp. 83-107). Washington DC: Institute for International Economics.

Mauro, P. (1998). Corruption: Causes, Consequences, and Agenda for Further Research (pp. 11-14). Washington DC: Finance and Development (International Monetary Fund), March.

Méon, P. G., \& Weill, L. (2010). Is Corruption an Efficient Grease? World Development, 38, 244-259. https://doi.org/10.1016/j.worlddev.2009.06.004

Millo, G., \& Piras, G. (2012). SPLM: Spatial Panel Data Models in R. Journal of Statistical Software, 47, 1-38. https://doi.org/10.18637/jss.v047.i01

Mo, P. H. (2001). Corruption and Economic Growth. Journal of Comparative Economics, 29, 66-79. https://doi.org/10.1006/jcec.2000.1703

Mutl, J., \& Pfaffermayr, M. (2011). The Hausman Test in a Cliff and Ord Panel Model. Econometrics Journal, 14, 48-76. https://doi.org/10.1111/j.1368-423X.2010.00325.x

Myrdal, G. (1989). Corruption: Its Causes and Effects. In A. Heidenheimer, M. Johnston, \& V. T. LeVine (Eds.), Political Corruption: A Handbook (pp. 953-961). Rutgers, NJ: Transaction Publishers.

Pellegrini, L., \& Gerlagh, R. (2004). Corruption's Effect on Growth and Its Transmission Channels. KYKLOS, 57, 429-456. https://doi.org/10.1111/j.0023-5962.2004.00261.x

Pesaran, H. (2004). General Diagnostic Tests for Cross Section Dependence in Panels. CESIfo Working Paper 1229.

Reinikka, R., \& Svensson, J. (2005). Fighting Corruption to Improve Schooling: Evidence from a Newspaper Campaign in Uganda. Journal of the European Economic Association, 3, 259-267. https://doi.org/10.1162/jeea.2005.3.2-3.259

Rey, S. J., \& Montouri, B. D. (1999). US Regional Income Convergence: A Spatial Econo- 
metric Perspective. Regulatory Studies, 33, 143-156.

https://doi.org/10.1080/00343409950122945

Sharma, C., \& Mitra, A. (2019). Corruption and Economic Growth: Some New Empirical Evidence from a Global Sample. Journal of International Development, 31, 691-719. https://doi.org/10.1002/jid.3433

Solé-Ollé, A., \& Sorribas-Navarro, P. (2018). Trust No More? On the Lasting Effects of Corruption Scandals. European Journal of Political Economy, 55, 185-203. https://doi.org/10.1016/j.ejpoleco.2017.12.003

Thach, N. N., Duong, M. B., \& Oanh, T. T. K. (2017). Effects of Corruption on Economic Growth-Empirical Study of Asia Countries. Imperial Journal of Interdisciplinary Research, 7, 791-804.

Wang, L. Y. (2016). The Impacts of Anti-Corruption on Economic Growth in China. Modern Economy, 7, 109-117. https://doi.org/10.4236/me.2016.72013

Wooldridge, J. M. (2010). Econometric Analysis of Cross-Section and Panel Data (2nd ed., pp. 310-312, Sec. 10.5.4). Cambridge, MA: MIT Press.

Zaki, C. (2013). Trade Facilitation and Corruption: A CGE Model of Egypt. The Journal of North African Studies, 18, 70-111. https://doi.org/10.1080/13629387.2012.731165 